\title{
Cell-Free Therapy may Experience More Rapid Advancement "Pretended Bystander Effects" in Cell-Based Therapy for Treating Diseases
}

\author{
Dingwei PENG ${ }^{*}$, Xiping YANG ${ }^{*}$, Lixia ZHANG ${ }^{*}$, Xingyi SONG ${ }^{*}$, Tao JIANG ${ }^{3}$, Yuetong HUI ${ }^{3}$, Lei WANG ${ }^{4}$, \\ Chongzhi SHANG ${ }^{1}$, Huipeng MENG ${ }^{5}$, Yanlong ZHANG $^{5}$, Ping WANG ${ }^{5}$, Huajiang DONG ${ }^{3}$, Keqiang WANG ${ }^{5,6}$ \\ ${ }^{1}$ Characteristic Medical Center of Chinese People's Armed Police Forces, Department of Neurosurgery, Tianjin, China \\ ${ }^{2}$ Characteristic Medical Center of Chinese People's Armed Police Forces, Department of Pediatrics, Tianjin, China \\ ${ }^{3}$ Logistics University of Chinese People's Armed Police Forces, Tianjin, China \\ ${ }^{4}$ Chinese Academy of Medical Sciences \& Peking Union Medical College, Institute of Biomedical Engineering, Tianjin, China \\ ${ }^{5}$ Tianjin University, Department of Biomedical Engineering, Tianjin, China \\ ${ }^{6}$ Tianjin Medical University General Hospital, Department of Radiotherapy, Tianjin, China \\ *These authors are the co-first authors.
}

Corresponding author: Keqiang WANG, Huajiang DONG wokyster@aliyun.com, dhj_424@163.com

To the Editor;

$\mathrm{W}$ e read with great interest that the article by Chen et al. entitled "Protective Effect of adenovirus (Ad)VEGF-Bone Mesenchymal Stem Cells on Cerebral Infarction" in Turkish Neurosurgery (1). In this article, Chen et al. reported that "intracerebroventricular transplantation of vascular endothelial growth factor (VEGF) gene-modified bone mesenchymal stem cells (BMSCs) in rats after cerebral infarction could reduce reactive gliosis, ameliorate neurological deficit, diminish the percentage of cerebral infarction volume in rats, and facilitate angiogenesis" (1).

We agree with the conclusions drawn from Chen et al. (1). MSCs-based therapies were anticipated to repair the structure and function of diseased or damaged tissues via direct cell replacement and/or pretended by-stander effect. More recently, MSC-derived extracellular vesicles (EVs), which include exosomes and microvesicles (MV), are being examined for their role in MSC-based cellular therapy. The exosomes and MVs can influence tissue responses to injury, infection, and disease (4). MSCs-free therapy maybe a promising therapy to treat some diseases, especially some intractable disease.
MSC-derived exosomes have a content that includes cytokines, exosomes, growth factors, signaling lipids, mRNAs, and regulatory miRNAs, etc. To the extent that MSC derived exosomes can be used for cell-free regenerative medicine, much will depend on the quality, reproducibility, and potency of their production, in the same manner that these parameters dictate the development of cell-based MSC therapies. Therefore, careful attention to detail in producing MSC exosomes may provide a new therapeutic paradigm for cell-free MSC-based therapies with decreased risk (5). We hold the opinion that both "Pretended Bystander Effects" (2) and Cell Replacement play a therapeutic role together $(2,3)$. In the process of cell therapy, the former is the main one at the early stage (about a month after cell therapy) and the latter at the later stage (usually a month after cell therapy) (7).

We believed that stem cell free therapy would experience more rapid advancement in the future. The advantages of MSC-free therapy could avoid the transfer of cells which may block the microvessels; and the MSC-derived exosomes, growth factors, signaling lipids, mRNAs, and regulatory miRNAs are small which could circulate readily $(5,6)$, and most of all MSCfree therapy can regulate the therapeutic doses scientifically. Therefore, careful attention to "MSC-free" treatment may provide a new therapeutic paradigm for MSC-based therapies.
Dingwei PENG (D): 0000-0001-8112-5902

Xiping YANG (D): 0000-0003-3583-813X

Lixia ZHANG (1): 0000-0001-5745-7157

Tao JIANG : : 0000-0002-6355-302X

$\begin{array}{ll}\text { Yuetong HUI } & \text { (D) : }: 0000-0001-7248-5481 \\ \text { Lei WANG } & \text { (D) : } 0000-0002-2931-8317 \\ \text { Chongzhi SHANG } & \text { (D) : 0000-0001-7207-9115 } \\ \text { Huipeng MENG } & \text { (D) : } 0000-0002-7947-1360\end{array}$

Lei WANG (D): 0000-0002-2931-8317

Huipeng MENG (1) : 0000-0002-7947-1360
Yanlong ZHANG (1) : 0000-0001-8358-7166

Ping WANG (1): 0000-0001-7517-8688

Huajiang DONG (1) : 0000-0002-4141-3077

Keqiang WANG (1) : 0000-0003-4813-4537 


\section{FUNDING}

This work was supported by the National Natural Science Foundation of China (81801240,31570985).

\section{REFERENCES}

1. Chen B, Zhang F, Li QY, Gong A, Lan Q: Protective effect of ad-vegf-bone mesenchymal stem cells on cerebral infarction. Turk Neurosurg 26:8-15, 2016

2. Dong HJ, Peng D, Zhao M, Wang L, Luo Y: Meeting prometheus: The mechanism of MSC-based therapies-cell replacement or "pretended bystander effects"? Turk Neurosurg 29(4):622623, 2019

3. Dong HJ, Zhao ML, Li XH, Chen YS, Wang J, Chen MB, Wu S, Wang JJ, Liang HQ, Sun HT, Tu Y, Zhang S, Xiong J, Chen C: Hypothermia-modulating matrix elasticity of injured brain promoted neural lineage specification of mesenchymal stem cells. Neuroscience 377:1-11, 2018
4. Komaki M, Numata Y, Morioka C, Honda I, Tooi M, Yokoyama $\mathrm{N}$, Ayame H, Iwasaki K, Taki A, Oshima N, Morita I: Exosomes of human placenta-derived mesenchymal stem cells stimulate angiogenesis. Stem Cell Res Ther 8:219, 2017

5. Phinney DG, Pittenger MF: Concise review: MSC-derived exosomes for cell-free therapy. Stem Cells 35:851-858, 2017

6. Savukinas UB, Enes SR, Sjoland AA, Westergren-Thorsson G: Concise review: The bystander effect: Mesenchymal Stem Cell-Mediated Lung Repair. Stem Cells 34:1437-1444, 2016

7. Wang $Y$, Peng $D$, Yang $X$, Huang $P$, Ye H, Hui $Y$, Wang $X$, Sun W, Wu H, Zhang S, Wang L, Sha $\mathrm{H}$, Shang C, Dong $\mathrm{H}$, Hu Q: Study on umbilical cord-matrix stem cells transplantation for treatment of acute trauma brain injury in rats. Turk Neurosurg 29(5):750-758, 2019 